(RESEARCH ARTICLE)

\title{
Assessment of the salinity level of water and sediments used for irrigation and agricultural farming in Jos north
}

\author{
Samuel Paul 1, ${ }^{*}$, Akintunde Sheyi ${ }^{2}$, Iliya Daniel Bangu ${ }^{3}$, Musa Bashir ${ }^{1}$, Jacob Joseph ${ }^{4}$ and Sani Idris \\ Abubakar ${ }^{3}$ \\ ${ }^{1}$ Department of Chemical Sciences, Federal University, Kashere P.M.B 0182 Gombe State Nigeria. \\ ${ }^{2}$ Department of Science Laboratory Technology, Federal College of Forestry Jos, P.M.B 2019, Plateau State, Nigeria. \\ ${ }^{3}$ Department of Soil Science, Federal University, Kashere P.M.B 0182 Gombe State Nigeria. \\ ${ }^{4}$ Department of Agricultural Extension and Management, Federal College of Horticulture, Dadin-Kowa P.M.B 108 Gombe \\ State Nigeria.
}

Publication history: Received on 06 October 2020; revised on 19 October 2020; accepted on 23 October 2020

Article DOI: https://doi.org/10.30574/wjarr.2020.8.1.0372

\begin{abstract}
Irrigated agriculture is dependent on an adequate water supply of usable quality. The different Irrigation sites were identified randomly, and named A, B, C, D and E respectively. Therefore, water and sediment or soil samples were collected from Rukuba Road River, Yelwan Zangam River, Gangare River, Busa Buji River and Angwan Rimi River respectively in Jos, Plateau State, Nigeria to evaluate their salinity level suitability for irrigation purpose and Agricultural Farming. The analytical results shows that the Electrical conductivity (EWc), Total dissolve solids (TDS), Sodium adsorption ratio (SAR) and specific ion toxicities of water and sediment are as followed: Rukuba Road River "A" (ECw = $508.00 \mu \mathrm{s} / \mathrm{cm}, 897.00 \mu \mathrm{s} / \mathrm{cm}$; TDS = $440.50 \mathrm{mg} / \mathrm{l}, 540.60 \mathrm{mg} / \mathrm{l}$ and SAR = 12.73, ND), Yalwan Zangam River "B" ( ECw = $750.00 \mu \mathrm{s} / \mathrm{cm}, 987.00 \mu \mathrm{s} / \mathrm{cm}$; TDS $=330.20 \mathrm{mg} / \mathrm{l}, 470.50 \mathrm{mg} / \mathrm{l}$ and SAR $=12.56$, ND), Gangare River “C” $(\mathrm{ECW}=$ $489.00 \mu \mathrm{s} / \mathrm{cm}, 897.00 \mu \mathrm{s} / \mathrm{cm}$; TDS $=40.70 \mathrm{mg} / \mathrm{l}, 550.90 \mathrm{mg} / \mathrm{l}$ and SAR $=13.16$, ND), Busa Buji River "D” (ECw $=$ $250.00 \mu \mathrm{s} / \mathrm{cm}, 499.00 \mu \mathrm{S} / \mathrm{cm}$; TDS $=355.60 \mathrm{mg} / \mathrm{l}, 495.00 \mathrm{mg} / \mathrm{l}$ and SAR $=14.06, \mathrm{ND})$ and Angwan Rimi River "E" (ECw = $1030.00 \mu \mathrm{s} / \mathrm{cm}, 1233.00 \mu \mathrm{s} / \mathrm{cm}$; TDS $=460.00 \mathrm{mg} / \mathrm{l}, 610.60 \mathrm{mg} / \mathrm{l}$ and SAR $=11.20$, ND). The salinity of river A B C D fall within the normal ranges which were of excellent quality and considered to be highly suitable without any restriction on the use. Water and sediment from Angwan River "E" (ECw $=1030.00 \mu \mathrm{s} / \mathrm{cm}, 1233.00 \mu \mathrm{s} / \mathrm{cm}$; TDS $=460.00 \mathrm{mg} / \mathrm{l}$, $610.60 \mathrm{mg} / \mathrm{l}$ and SAR $=19.20$, ND) will be highly suitable under proper management such as improved irrigation system and schedule, light soil with good infiltration and internal drainage and plant with good salt tolerant. The variation in chemical composition of the irrigation water and sediment sources could be attributed to the fact that the Angwan Rimi River "E" water and sediment sources are located within Jos metropolis. The additions from waste waters (domestic sewage and municipal), dirt and suspended inorganic matter and automobile effluents from Mechanic workshops could contributes to the high levels of Salinity, SAR and Total hardness and specific ion toxicities of the irrigation water.
\end{abstract}

Keywords: Electrical conductivity; Total dissolve solids; Sodium adsorption ratio; Specific ion toxicities; waste waters

\section{Introduction}

Water is the most important input required for plant growth in agricultural production. Bulk weight of all living organisms consists of 80 to $90 \%$ water [1]. Where the available soil moisture derived from rain is deficient, this lack can be made up by irrigation [2]. Conceptually, water quality refers to the characteristic of a water supply that will influence its suitability for a specific use, i.e., how well the quality meets the needs of the user. To evaluate the suitability of water supply for irrigation, information is required on its quality and quantity.

\footnotetext{
${ }^{*}$ Corresponding author: Samuel Paul

Department of Chemical Sciences, Federal University, Kashere P.M.B 0182 Gombe State Nigeria.
} 
Irrigation water quality is a key environmental issue faced by agricultural sector as well as it is very important for every agricultural use, passing through such activities as irrigation to livestock watering, from safe household family drinkable water on farms. [3]. [4] reported that human activities that involved urbanization, agricultural activities, over use of fertilizers / chemicals, inadequate management of land use and sewage disposal have directly or indirectly affected the quality of water and making it unsuitable for irrigation. Poor quality water may affect irrigated crops by causing accumulation of salts in the root zone, by causing loss of permeability of the soil due to excess sodium or calcium leaching, or by containing pathogens or contaminants which are directly toxic to plants or to those consuming them [5], [6]. Agricultural water sources may be of poor quality because of natural causes, contamination or both, and often requires improvement before it is acceptable for a given use [7], [8]. A major concern for water use for irrigation is decreased crop yields and land degradation as a result of excess salts being present in water and soils.

The soil problems most commonly encountered and used as a basis to evaluate water quality are those related to salinity hazard, water infiltration rates (sodium hazard), specific ion toxicities and a group of other miscellaneous problems. And of these, salinity and / or sodium hazard is the most prevalent problem associated with irrigation water.

Therefore, the objective of the present study was to evaluate the chemical status of the waters and sediments of the study area with respect to $\mathrm{pH}$, Electrical Conductivity (ECw), Total Dissolve Solids (TDS), Sodium Adsorption Ratio (SAR) and specific ions such as Sodium $\left(\mathrm{Na}^{+}\right)$, Magnesium $\left(\mathrm{Mg}^{2+}\right)$, Calcium $\left(\mathrm{Ca}^{2+}\right)$, Potassium $\left(\mathrm{K}^{+}\right)$, Boron (B), Bicarbonate $\left(\mathrm{HCO}_{3}{ }^{-}\right)$, Chloride $\left(\mathrm{Cl}^{-}\right)$and Nitrate $\left(\mathrm{NO}_{3}^{-}\right)$and hence to ascertain their suitability for irrigation purpose.

\section{Material and methods}

Turbid meter (6035), spectrophotometer, pipette, plasticine, forceps, capillary tube, incubator, foil paper, petri dishes, filter paper, magnetic stirrer, desiccator, weighing balance, HACH conductivity meter, Atomic absorption spectrophotometer (AAS), distillation flask, beakers, retort stand, separating funnel, measuring cylinder (500ml), blender (1.2 liters), beakers, syringe, $1 \mathrm{ml}$ plastic, palintest photometer, conical flask, burette, $\mathrm{pH}$ meter, mercury in glass thermometer.

\subsection{Location of investigation area}

The study area is Jos North, a Local Government Area (L.G.A) in Plateau State located in Nigeria's middle belt. Its headquarters is in the town of Jos at 9o $32^{\prime} 00^{\prime \prime} \mathrm{N} 8^{\circ} 5400^{\prime \prime} \mathrm{E} / 9.53333^{\circ} \mathrm{N} 8.90000^{\circ} \mathrm{E}$. It has an area of 1,032 square kilometers and a population of 175,267 as of the 2006 census.

\subsection{Collection of water sample}

The different Irrigation sites were identified randomly, and named A, B, C, D and E respectively. The water and sediment or soil samples were collected from five different rivers used for irrigation in Jos North LGA. Irrigation water samples were taken from the fasted flowing part, the midway along the width of the river. The 4L water samples were collected using sterilized plastic bottles, labeled as stated above, were taken to the laboratory, analyzed and subsequently stored in a refrigerator. Each $400 \mathrm{~g}$ soil sample was also collected in a plastic container using a plastic spoon to scoop. Proper storage, transportation and handling of samples were observed to prevent change in physical properties (Standard method of analysis, WHO \& UNESCO, 1984) [9].

Water samples were analyzed for $\mathrm{pH}$ using electrometric $\mathrm{pH}$ meter according to procedure described by [10]. Concentration of total dissolve solids, electrical conductivity, boron and chloride were determined using standard methods [11]. Calcium and magnesium ions were determined by Atomic Adsorption Spectrophotometer (AAS), sodium and potassium ions were determined by flame photometry. Phosphorus was determined by the Bray P 1 method [12] while nitrate and bicarbonate was determined by titration method.

\subsubsection{Sediment Sampling and Treatment}

Each $400 \mathrm{~g}$ of the sediment sample was collected in plastic containers, using a plastic spoon to scoop. These were mixed, dried, ground in a mortar and sieved through a $200 \mathrm{~mm}$ mesh. The sediment samples were prepared by sediment to water extraction method; where the sediment was digested with water (distilled water) in the ratio of $1: 5$, shaken vigorously in a mechanical shaker and filtered through a high retentive filter paper (Watmann No:3). Analysis is then carried out on the prepared samples. Proper storage, transportation and handling of samples were observed to prevent change in physical properties (standard method of analysis, WHO \& UNESCO, 1984) [13]. 


\section{Results}

Table 1 Salinity level of river "a" (rukuba road) and its sediment.

\begin{tabular}{|c|c|c|c|c|}
\hline PARAMENTERS AND UNITS & WATER & SEDIMENT & $\begin{array}{c}\text { WHO } \\
\text { STANDARDS }\end{array}$ & $\begin{array}{l}\text { FAD } \\
\text { STANDARDS }\end{array}$ \\
\hline $\mathrm{pH}$ & $6.95 \pm 0.05$ & $7.50 \pm 0.05$ & $6.50-8.50$ & $6.50-8.40$ \\
\hline Temperature $\left({ }^{\circ} \mathrm{C}\right)$ & $25.20 \pm 0.49$ & $18.30 \pm 0.97$ & 25.00 & 25.00 \\
\hline Conductivity $(\mu \mathrm{s} / \mathrm{cm})$ & $508.00 \pm 43.80$ & $897.00 \pm 44.80$ & 1000.00 & 1000.00 \\
\hline $\mathrm{CO}_{3}^{-}(\mathrm{mg} / \mathrm{l})$ & $18.50 \pm 1.40$ & ND & NS & 61.00 \\
\hline $\mathrm{CO}_{3}{ }^{2-}(\mathrm{mg} / \mathrm{l})$ & $152.50 \pm 21.11$ & ND & NS & 300.00 \\
\hline Boron $(\mathrm{mg} / \mathrm{l})$ & $0.25 \pm 0.02$ & $0.22 \pm 0.04$ & NS & $0.00-2.00$ \\
\hline Sodium (mg/l) & $414.00 \pm 21.31$ & $389.00 \pm 24.02$ & NS & 920.00 \\
\hline Chloride (mg/l) & $46.00 \pm 2.89$ & $76.00 \pm 1.89$ & 250.00 & 350.00 \\
\hline TDS (mg/l) & $440.50 \pm 10.32$ & $540.60 \pm 20.51$ & 450.00 & $0.00-2000.00$ \\
\hline $\mathrm{NH}_{4}^{+}(\mathrm{mg} / \mathrm{l})$ & $4.14 \pm 1.11$ & $4.67 \pm 1.02$ & NS & $0.00-5.00$ \\
\hline $\mathrm{PO}_{4}^{2-}(\mathrm{mg} / \mathrm{l})$ & $1.73 \pm 0.37$ & ND & NS & $0.00-2.00$ \\
\hline SAR (mg/l) & $12.73 \pm 2.12$ & ND & NS & $0.00-15.00$ \\
\hline
\end{tabular}

Table 2 Salinity level of river ' $b$ ' (yelwan zangam) and its sediment.

\begin{tabular}{|l|l|l|l|l|}
\hline $\begin{array}{l}\text { PARAMENTS } \\
\text { AND WATER }\end{array}$ & WATER & SEDIMENT & $\begin{array}{c}\text { WHO } \\
\text { STANDARDS }\end{array}$ & $\begin{array}{c}\text { FAO } \\
\text { STANDARDS }\end{array}$ \\
\hline $\mathrm{pH}$ & $6.70 \pm 0.03$ & $7.65 \pm 0.04$ & $6.50-8.50$ & $6.50-8.40$ \\
\hline Temperature $\left({ }^{\circ} \mathrm{C}\right)$ & $24.20 \pm 0.36$ & 16.80 & 25.00 & 25.00 \\
\hline Conductivity $(\mu \mathrm{s} / \mathrm{cm})$ & $750.00 \pm 66.30$ & $987.00 \pm 78.90$ & 1000.00 & 1000.00 \\
\hline $\mathrm{CO}_{3}{ }^{-}(\mathrm{mg} / \mathrm{l})$ & $11.70 \pm 3.11$ & $\mathrm{ND}$ & $\mathrm{NS}$ & 61.00 \\
\hline $\mathrm{CO}_{3}{ }^{2-}(\mathrm{mg} / \mathrm{l})$ & $225.70 \pm 22.52$ & $\mathrm{ND}$ & $\mathrm{NS}$ & 300.00 \\
\hline Boron $(\mathrm{mg} / \mathrm{l})$ & $0.33 \pm 0.05$ & $0.27 \pm 0.08$ & NS & $0.00-2.00$ \\
\hline Sodium $(\mathrm{mg} / \mathrm{l})$ & $483.00 \pm 18.92$ & $443.00 \pm 23.02$ & NS & 920.00 \\
\hline $\mathrm{Chloride}(\mathrm{mg} / \mathrm{l})$ & 64.003 .72 & $99.40 \pm 1.88$ & 250.00 & 350.00 \\
\hline TDS $(\mathrm{mg} / \mathrm{l})$ & $330.20 \pm 10.29$ & $470.50 \pm 12.7$ & 450.00 & $0.00-2000.00$ \\
\hline $\mathrm{NH}_{4}{ }^{+}(\mathrm{mg} / \mathrm{l})$ & $3.78 \pm 1.72$ & $4.03 \pm 1.24$ & NS & $0.00-5.00$ \\
\hline $\mathrm{PO}_{4}{ }^{2-}(\mathrm{mg} / \mathrm{l})$ & $1.67 \pm 0.26$ & ND & NS & $0.00-2.00$ \\
\hline $\mathrm{SAR}^{-\mathrm{mg} / \mathrm{l})}$ & $12.56 \pm 3.67$ & ND & NS & $0.00-15.00$ \\
\hline
\end{tabular}


Table 3 Salinity level of river 'c' (gangare) its sediment.

\begin{tabular}{|c|c|c|c|c|}
\hline $\begin{array}{l}\text { PARAMENTERS } \\
\text { AND UNITS }\end{array}$ & WATER & SEDIMENT & $\begin{array}{c}\text { WHO } \\
\text { STANDARDS }\end{array}$ & $\begin{array}{c}\text { FAO } \\
\text { STANDARDS }\end{array}$ \\
\hline $\mathrm{pH}$ & $6.90 \pm 0.14$ & $7.65 \pm 0.12$ & $6.50-8.50$ & $6.50-8.40$ \\
\hline Temperature $\left({ }^{\circ} \mathrm{C}\right)$ & $25.10 \pm 0.46$ & $16.00 \pm 2.30$ & 25.00 & 25.00 \\
\hline Conductivity ( $\mu \mathrm{s} / \mathrm{cm})$ & $489.00 \pm 37.30$ & $897.00 \pm 40.40$ & 1000.00 & 1000.00 \\
\hline $\mathrm{CO}_{3}^{-}(\mathrm{mg} / \mathrm{l})$ & $18.50 \pm 1.73$ & ND & NS & 61.00 \\
\hline $\mathrm{CO}_{3}{ }^{2-}(\mathrm{mg} / \mathrm{l})$ & $140.91 \pm 25.10$ & ND & NS & 300.00 \\
\hline Boron (mg/l) & $0.27 \pm 0.04$ & $0.25 \pm 0.02$ & NS & $0.00-2.00$ \\
\hline Sodium (mg/l) & $391.00 \pm 27.11$ & $369.00 \pm 30.02$ & NS & 920.00 \\
\hline Chloride (mg/l) & $42.00 \pm 3.24$ & $68.20 \pm 2.21$ & 250.00 & 350.00 \\
\hline TDS (mg/l) & $40.70 \pm 0.30$ & $550.90 \pm 0.82$ & 450.00 & $0.00-2000.00$ \\
\hline $\mathrm{NH}_{4}{ }^{+}(\mathrm{mg} / \mathrm{l})$ & $3.60 \pm 1.22$ & $3.87 \pm 1.12$ & NS & $0.00-5.00$ \\
\hline $\mathrm{PO}_{4}{ }^{2-}(\mathrm{mg} / \mathrm{l})$ & $1.76 \pm 0.89$ & ND & NS & $0.00-2.00$ \\
\hline $\mathrm{SAR}(\mathrm{mg} / \mathrm{l})$ & $13.16 \pm 2.33$ & ND & NS & $0.00-15.00$ \\
\hline
\end{tabular}

Table 4 Salinity level of river'd' (busa buji) and its sediment.

\begin{tabular}{|c|c|c|c|c|}
\hline $\begin{array}{l}\text { PARAMENTERS } \\
\text { AND UNITS }\end{array}$ & WATER & SEDIMENT & $\begin{array}{l}\text { WHO } \\
\text { STANDARDS }\end{array}$ & $\begin{array}{l}\text { FAO } \\
\text { STANDARDS }\end{array}$ \\
\hline $\mathrm{pH}$ & $6.58 \pm 0.06$ & $7.60 \pm 0.09$ & $6.50-8.50$ & $6.50-8.40$ \\
\hline Temperature $\left({ }^{\circ} \mathrm{C}\right)$ & $26.30 \pm 0.40$ & $15.00 \pm 2.12$ & 25.00 & 25.00 \\
\hline Conductivity $(\mu \mathrm{s} / \mathrm{cm})$ & $250.00 \pm 23.00$ & $499.00 \pm 17.90$ & 1000.00 & 1000.00 \\
\hline $\mathrm{CO}_{3}^{-}(\mathrm{mg} / \mathrm{l})$ & $9.90 \pm 2.17$ & ND & NS & 61.00 \\
\hline $\mathrm{CO}_{3}{ }^{2-}(\mathrm{mg} / \mathrm{l})$ & $203.74 \pm 29.60$ & ND & NS & 300.00 \\
\hline Boron (mg/l) & $0.28 \pm 0.03$ & $0.31 \pm 0.05$ & NS & $0.00-2.00$ \\
\hline Sodium (mg/l) & $506.00 \pm 33.26$ & $486.00 \pm 30.82$ & NS & 920.00 \\
\hline Chloride (mg/l) & $75.00 \pm 3.35$ & $98.00 \pm 2.57$ & 250.00 & 350.00 \\
\hline $\mathrm{NH}_{4}{ }^{+}(\mathrm{mg} / \mathrm{l})$ & $4.86 \pm 1.34$ & $3.99 \pm 1.56$ & NS & $0.00-5.00$ \\
\hline $\mathrm{PO}_{4}{ }^{2-}(\mathrm{mg} / \mathrm{l})$ & $1.82 \pm 0.26$ & ND & NS & $0.00-2.00$ \\
\hline TDS (mg/l) & $355.60 \pm 10.34$ & $495.00 \pm 10.93$ & 450.00 & $0.00-2000.00$ \\
\hline SAR (mg/l) & $14.06 \pm 2.11$ & ND & NS & $0.00-15.00$ \\
\hline
\end{tabular}


Table 5 Salinity level of river 'e' (angwan rimi) and its sediment.

\begin{tabular}{|c|c|c|c|c|}
\hline $\begin{array}{l}\text { PARAMENTERS } \\
\text { AND UNITS }\end{array}$ & WATER & SEDIMENT & $\begin{array}{c}\text { WHO } \\
\text { STANDARDS }\end{array}$ & $\begin{array}{c}\text { FAO } \\
\text { STANDARDS }\end{array}$ \\
\hline $\mathrm{pH}$ & $7.20 \pm 0.09$ & $9.75 \pm 1.02$ & $6.50-8.50$ & $6.50-8.40$ \\
\hline Temperature $\left({ }^{\circ} \mathrm{C}\right)$ & $23.22 \pm 0.39$ & $\begin{array}{l}17.00 \\
\pm 1.37\end{array}$ & 25.00 & 25.00 \\
\hline Conductivity $(\mu \mathrm{S} / \mathrm{cm})$ & $1030.00 \pm 89.30$ & $1233.00 \pm 96.77$ & 1000.00 & 1000.00 \\
\hline $\mathrm{CO}_{3^{-}}(\mathrm{mg} / \mathrm{l})$ & $7.50 \pm 0.27$ & ND & NS & 61.00 \\
\hline $\mathrm{CO}_{3}{ }^{\overline{\bar{z}}-}(\mathrm{mg} / \mathrm{l})$ & $250.10 \pm 32.31$ & ND & NS & 300.00 \\
\hline Boron (mg/l) & $0.44 \pm 0.02$ & $0.36 \pm 0.06$ & NS & $0.00-2.00$ \\
\hline Sodium (mg/l) & $345.00 \pm 29.21$ & $296.00 \pm 18.61$ & NS & 920.00 \\
\hline Chloride (mg/l) & $39.50 \pm 3.47$ & $60.8 \pm 7.89$ & 250.00 & 350.00 \\
\hline $\mathrm{NH}_{4}+(\mathrm{mg} / \mathrm{l})$ & $4.12 \pm 2.11$ & $5.23 \pm 2.16$ & NS & $0.00-5.00$ \\
\hline $\mathrm{PO}_{4}^{2-}(\mathrm{mg} / \mathrm{l})$ & $1.16 \pm 0.73$ & ND & NS & $0.00-2.00$ \\
\hline TDS (mg/l) & $460.00 \pm 20.37$ & $610.60 \pm 28.35$ & 450.00 & $0.00-2000.00$ \\
\hline SAR (mg/l) & $19.20 \pm 2.44$ & ND & NS & $0.00-15.00$ \\
\hline
\end{tabular}

KEY: ND = Not Detected; NS = Not Stated

Table 6 Physicochemical characteristic of the river water using WHO reference for drinking water

\begin{tabular}{|l|l|l|l|l|l|l|}
\hline $\begin{array}{l}\text { PARAMENTERS } \\
\text { UNITS }\end{array}$ & \multicolumn{1}{|c|}{$\mathbf{A}$} & \multicolumn{1}{|c}{ B } & \multicolumn{1}{|c|}{ C } & \multicolumn{1}{|c|}{ D } & \multicolumn{1}{|c|}{$\begin{array}{l}\text { WHO } \\
\text { STANDARD }\end{array}$} \\
\hline Temperature $\left({ }^{\circ} \mathrm{C}\right)$ & $25.20 \pm 0.49$ & $24.20 \pm 0.36$ & $25.10 \pm 0.46$ & $26.30 \pm 0.40$ & $23.22 \pm 0.39$ & $25.00-40.00$ \\
\hline pH & $6.95 \pm 0.04$ & $6.70 \pm 0.03$ & $6.90 \pm 0.14$ & $6.58 \pm 0.05$ & $7.20 \pm 0.09$ & $6.50-8.50$ \\
\hline Colour & Light brown & Cloudy & Light Brown & Colourless & Brown & Colourless \\
\hline Turbidity (NTU) & $5.00 \pm 0.74$ & $5.00 \pm 0.73$ & $5.00 \pm 0.74$ & $3.00 \pm 0.73$ & $5.00 \pm 0.71$ & 5.00 \\
\hline TSS (mg/l) & $532.00 \pm 0.25$ & $600.00 \pm 0.23$ & $5.00 \pm 0.27$ & $3.00 \pm 0.24$ & $5.00 \pm 0.30$ & 5.00 \\
\hline TDS (mg/l) & $440.50 \pm 0.32$ & $330.00 \pm 0.29$ & $400.70 \pm 0.30$ & $350.60 \pm 0.34$ & $460.00 \pm 0.37$ & 450.00 \\
\hline $\begin{array}{l}\text { Dissolved Oxygen } \\
\text { (mg/l) }\end{array}$ & $32.00 \pm 2.12$ & $29.00 \pm 1.41$ & $31.00 \pm 1.52$ & $29.00 \pm 1.77$ & $30.00 \pm 1.83$ & 30.00 \\
\hline Nitrate (mg/l) & $360.00 \pm 10.860$ & $300.00 \pm 14.80$ & $240.00 \pm 6.36$ & $480.00 \pm 12.70$ & $720.00 \pm 11.30$ & 500.00 \\
\hline Calcium (mg/l) & $450.00 \pm 12.00$ & $564.00 \pm 22.60$ & $444.00 \pm 14.10$ & $510.00 \pm 9.19$ & $592.00 \pm 23.80$ & 500.00 \\
\hline Magnesium (mg/l) & $43.80 \pm 2.69$ & $49.20 \pm 2.97$ & $38.40 \pm 2.40$ & $49.40 \pm 2.44$ & $37.20 \pm 2.37$ & 500.00 \\
\hline $\begin{array}{l}\text { Total Hardness } \\
\text { (mg/l) }\end{array}$ & $30.00 \pm 3.21$ & $36.00 \pm 2.34$ & $31.00 \pm 2.99$ & $31.00 \pm 3.10$ & $43.00 \pm 2.59$ & 150.00 \\
\hline Chlorides (mg/l) & $46.00 \pm 2.89$ & $64.00 \pm 3.72$ & $42.00 \pm 3.24$ & $75.00 \pm 3.35$ & $39.50 \pm 3.47$ & 250.00 \\
\hline Sulphates (mg/l) & $585.60 \pm 16.70$ & $667.20 \pm 24.90$ & $590.40 \pm 20.30$ & $456.00 \pm 14.00$ & $672.00 \pm 27.80$ & 400.00 \\
\hline
\end{tabular}




\section{Discussion}

Water as a universal solvent is colorless when in its purest form. Coloration of water is as a result of impurities like particulate matters (e.g. dust, fog) and natural metallic ions.

In these analysis the result shows that sample A, B, C and E had colors, while River D was colorless.

Temperature is an important water quality parameter because of its tendency to speed up chemical reactions and implication of taste and odor (WHO, 1984) there is no set standard for temperature which is known to vary depending on the atmospheric condition in the area.

The set standard by WHO and FAO is the ambient. The average temperature for Rivers A, B, C, D and E ranges from $15.00-26.00^{\circ} \mathrm{C}$.

This is a measure of $\mathrm{H}^{+}$by various presences of various dissolved components (WHO 1984). Expressed as ( $<7.00$ acidic $>7.00$ basic). In Nigeria the same standard for drinking water quality is used as for irrigation water. Therefore, WHO normal 6.00 - 8.50 was the basis for comparison of results, while 6.50 - 10.00 for sediments. All values for both water and sediments for Rivers A, B, C, D and E falls within the standard Irrigation water with pH outside the normal range may cause a nutritional imbalance.

Electrical conductivity is the ability of a solution to transit an electrical current. The higher the EC the less water is available to plant even though soil may appear moist, from the result obtained in table 1, the EC values ranges from 250.00-1233.00 $\mu \mathrm{s} / \mathrm{cm}$, the highest EC value for river water was obtained $1030.00 \mu \mathrm{S} / \mathrm{cm}$ while for sediments 1233.00 $\mu \mathrm{s} / \mathrm{cm}$ both in river E, while for Rivers A-D falls within the WHO affordable EC levels of between 250.00-1000.00 $\mu \mathrm{s} / \mathrm{cm}$

The values of TDS which in river water has a normal value of $450.00 \mathrm{mg} / \mathrm{dl}$ while for sediments $500.00 \mathrm{mg} / \mathrm{dl}$ comparing this with results obtained both river and sediments for river A and E showed values higher than the WHO standards with values of $440.50 \mathrm{mg} / \mathrm{dl}, 540.60 \mathrm{mg} / \mathrm{dl}$ (River A) and $460.00 \mathrm{mg} / \mathrm{dl}$ and $610.6 .00 \mathrm{mg} / \mathrm{dl}$ (River E) for water and sediments respectively, while rivers $C$ showed sediment value of $550.90 \mathrm{mg} / \mathrm{ml}$.

Similarly, Total suspended solids (TSS) with a WHO standard of $500.00,800.00 \mathrm{mg} / \mathrm{dl}$ values for water and sediments showed an increase above normal from Rivers A-E. With maximum value of 797.00mg/dl at River E for sediment. Dissolved oxygen is used for survival of aquatic organisms such as plantations, amphibians and fishes to thrive well. The reference by WHO for water is $30.00 \mathrm{mg} / \mathrm{l}$, with only water values for Rivers A and River C above normal readings $32.00 \mathrm{mg} / \mathrm{l}$ and $31.00 \mathrm{mg} / \mathrm{l}$ respectively.

Because of dissolving action of ground water, spring water is naturally expected to contain much of hardness ions. These metal include Magnesium and calcium hardness, alkali earth metals that are in form of $\mathrm{Ca}^{2+}$ and $\mathrm{Mg}^{2+}$ ions cause hardness in water. Calcium and $\mathrm{Mg}^{2+} 500.00 \mathrm{mg} / \mathrm{l}$ for drinking water. Had values all above the WHO reference. Therefore, makes water not suitable for drinking.

Due to leaching of discharges of effluent and domestic waste or solvent action of water, sprig water most often contains sulphate. The values of sulphate obtained in the samples all fall within the WHO standard. This may be attributed to the fact that there are no industries around the specimen sites or anywhere near it. Sulphate can only be attributed to natural salvation action by water.

The presence of nitrate is probably due to the presence of nitrogen organic matter and to some extent of vegetable origin, therefore only small quantity is naturally present in water and sediments. WHO standards recommend $0-10 \mathrm{me} / \mathrm{L}$ and 0-12 me/L for water and sediments respectively. The nitrate obtained in the entire sample are significantly low except for River $\mathrm{E}$ which showed a slight increase with values of $12 \mathrm{me} / \mathrm{l}$ and $15 \mathrm{me} / \mathrm{l}$ for water and sediments respectively.

\section{Conclusion}

The results of the parameters used to access the salinity level of five flowing rivers and sediments used for irrigation and agricultural purposes in Jos North LGA were compared with the WHO standards. 
The salinity parameters analyzed included TDS, TSS and EC with values for ECe and ECw within normal, as shown in the table 1 above one can deduce that for Rivers A-D the salinity falls within the normal ranges.

While for River E, the salinity parameters were above WHO recommended values ECw at $1030.00 \mu \mathrm{S} / \mathrm{cm}$, ECe $1233.00 \mu \mathrm{S} / \mathrm{Cm}$, observed effects of said salinity in these environment include reduced growth, loss of clovers and medics from pastures and invasion by salt - tolerant weeds (e.g. sea- barley grass).

\section{Compliance with ethical standards}

\section{Acknowledgments}

This research did not receive any form of grant from government or non-governmental organization.

\section{Disclosure of conflict of interest}

The authors declare that they have no known competing financial interests or personal relationships that could have appeared to influence the work reported in this paper.

\section{References}

[1] Christiansen JE, Olsen EC, Willard LS. Irrigation water. J. Irrigation and Drainage Div., ASCE. 1977; 103: 155 - 169.

[2] George PR. Agricultural water quality criteria: Irrigation Aspect. Res. Mgt. Tech. Report No. 30. Department of Agriculture, Western Australia. 2004.

[3] Shainberg I, Oster JD. Quality of irrigation water. I.I.I.C. Publication No. 2. (Int. Irri. Inf. Centre, Isreal). 1978.

[4] Rowe DR, Abdelmagid IM. Hand book of waste water reclamation and Re use. CRC Pres, Inc. 1995; 550.

[5] Rhoades JD. Quality of irrigation water. Soil Sci. 1972; 113: 277 - 284.

[6] Cooper CM, Lipe WM. Water quality and agriculture: Mississippi experience. J. Soil and Water Con. 1992; 47(3): $220-223$.

[7] Ayers RS. Quality water for irrigation. J. Irrigation and Drainage Div., ASCE. 1977; 103: 135 - 154.

[8] Anikwe MAN, Ofoke PE, Mbah CN. Relationship between irrigation water quality and salinization of selected irrigated soils in Abakaliki, Southeastern, Nigeria. Nig. J. Soil Res. 2002; 47(3): 220 - 223.

[9] George P, Schultzu S. Notifies UNESCO of intent to withdraw. Department of State Bulletin. 1984; 84: 41-42.

[10] McLean EO. Soil pH and lime requirement. In page AL, Miller RH, Keeney DR. (Eds). Methods of soil analyses part 2- Chemical and microbiological properties. (2 ${ }^{\text {nd }}$ Ed.). Amer. Soc. of Agron., Soil Sci. Soc. 1982; 9: $199-224$.

[11] APHA. Standard methods for Examination of water and waste water (17th Edition); prepared and published jointly by: American Public Health Association (APHA); America Water Works Association (AWWA) and Water Pollution Control Federation (WPFC), New York. 1989.

[12] Bray RH, Kurtz LT. Determination of total, organic and available forms of phosphorus in soils. Soil Sci. 1945; 59: $39-45$.

[13] George P, Schultzu S. Notifies UNESCO of intent to withdraw. Department of State Bulletin. 1984; 84: 41-42. 